\title{
Wt1 deficiency causes undifferentiated spermatogonia accumulation and meiotic progression disruption in neonatal mice
}

\author{
Qiao-Song Zheng ${ }^{1,2}$, Xiao-Na Wang ${ }^{1,2}$, Qing Wen ${ }^{1,2}$, Yan Zhang ${ }^{1}$, Su-Ren Chen ${ }^{1,2}$, Jun Zhang ${ }^{1,2}$, \\ Xi-Xia Li ${ }^{1,2}$, Ri-Na Sha ${ }^{1,2}$, Zhao-Yuan Hu${ }^{1}$, Fei Gao ${ }^{1}$ and Yi-Xun Liu ${ }^{1}$ \\ ${ }^{1}$ State Key Laboratory of Reproductive Biology, Institute of Zoology, Chinese Academy of Sciences, Beijing 100101, \\ China and ${ }^{2}$ Graduate School of the Chinese Academy of Sciences, Beijing, China
}

Correspondence should be addressed to Y-X Liu; Email: liuyx@ioz.ac.cn; F Gao; Email: gaofei72@yahoo.com

\begin{abstract}
Spermatogenesis is a complex process involving the regulation of multiple cell types. As the only somatic cell type in the seminiferous tubules, Sertoli cells are essential for spermatogenesis throughout the spermatogenic cycle. The Wilms tumor gene, Wt1, is specifically expressed in the Sertoli cells of the mouse testes. In this study, we demonstrated that Wt1 is required for germ cell differentiation in the developing mouse testes. At 10 days post partum, Wt1-deficient testes exhibited clear meiotic arrest and undifferentiated spermatogonia accumulation in the seminiferous tubules. In addition, the expression of claudin11, a marker and indispensable component of Sertoli cell integrity, was impaired in $W t 1^{-/ f l o x}$; Cre-ER ${ }^{T M}$ testes. This observation was confirmed in in vitro testis cultures. However, the basal membrane of the seminiferous tubules in Wt1-deficient testes was not affected. Based on these findings, we propose that Sertoli cells' status is affected in Wt1-deficient mice, resulting in spermatogenesis failure.
\end{abstract}

Reproduction (2014) 147 45-52

\section{Introduction}

Spermatogenesis is a continuous and highly organized process that requires the participation of multiple cell types. Sertoli cells, which interact directly with developing germ cells in the testis throughout spermatogenesis, play an indispensable role in germ cell development (Mruk \& Cheng 2004). Wt1 functions as a transcriptional regulator and is essential for the development of several organs, such as the kidney, heart, and gonads (Chamindrani Mendis-Handagama \& Siril Ariyaratne 2001). Previous studies have demonstrated that $W t 1$ is required during the earliest stage of gonad development, prior to sexual differentiation, in mice (Luo et al. 1994, Klattig et al. 2007). Studies have also shown that $W t 1$ may be essential for later gonad development. The specific deletion of $W t 1$ in Sertoli cells during E12.5-E14.5 resulted in testicular cord disruption and testis dysgenesis (Gao et al. 2006). Intriguingly, the Wt1 mRNA levels in the testes still increased steadily after birth and reached their highest expression at 8 days post partum (dpp; Pelletier et al. 1991). Moreover, immunohistochemical studies confirmed that the WT1 protein is strongly expressed in the Sertoli cells associated with early spermatogonia, but not in the cells associated with late spermatogonia
(Suzuki \& Saga 2008). The spatiotemporal expression pattern of Wt1 suggests a potential role in the developing testis. However, the postnatal function of $\mathrm{Wt} 1$ has not been elucidated due to embryonic stage lethality in $W t 1^{-1-}$ mice (Bacon et al. 2003).

The objective of this study was to examine the function of $W t 1$ in the neonatal testes. Wt $1^{- \text {flox; }}$ Cre-ER $R^{T M}$ (tamoxifen-inducible) mice were treated with tamoxifen at $5 \mathrm{dpp}$ to inactivate $W t 1$ expression, and their phenotypes were examined at $10 \mathrm{dpp}$ ( 5 days after tamoxifen treatment). To exclude the potential effects of other organs after $W t 1$ inactivation, an in vitro testis culture model was employed to confirm the in vivo phenotype. The evidence showed that Wt1 deficiency caused undifferentiated spermatogonia accumulation to undergo a meiotic progression disruption and that claudin11 expression was impaired in the $W t 1^{-/ \text {flox }}$; Cre-ER ${ }^{T M}$ testes. Therefore, we suggest that $W t 1$ is essential for germ cell differentiation in the neonatal testes.

\section{Materials and methods}

\section{Animals}

All the mice were maintained on a C57BL/6; 129/SvEv mixed genetic background. Wt1 ${ }^{\text {flox/flox }}$ (Gao et al. 2006) mice were 
mated with mice carrying the Wt1-null allele $\left(W t 1^{+/-}\right.$; Kreidberg et al. 1993) and Cre-ER ${ }^{T M}$ (Hayashi \& McMahon 2002) transgenic mice to produce $W t 1^{- \text {fflox }}$; Cre- $E R^{T M}$ offspring. Tail DNA was used for PCR genotyping, as described previously (Harada et al. 1999, Gao et al. 2006). The mice were housed in cages under a $12 \mathrm{~h}$ light: $12 \mathrm{~h}$ darkness cycle. Two females were placed in a cage with one male in the evening and were examined for vaginal plugs the next morning. The day on which a vaginal plug was detected was designated as E0.5. All the animal procedures were approved by the committee of animal care at the Institute of Zoology, Chinese Academy of Sciences.

\section{Tamoxifen treatment}

Tamoxifen (Sigma) was dissolved in corn oil at a final concentration of $20 \mathrm{mg} / \mathrm{ml}$. Wt1 ${ }^{-/ \text {flox }} ; C r e-E R^{T M}$ and $W t 1^{-/ \text {flox }}$ (control) mice at $5 \mathrm{dpp}$ were treated with tamoxifen by i.p. injection at a dose of $9 \mathrm{mg} / 40 \mathrm{~g}$ body weight.

\section{Immunohistochemistry and immunofluorescence}

$W t 1^{-/ \text {flox }}$; Cre-ER $R^{T M}$ and $W t 1^{-/ \text {flox }}$ (control) mice at $5 \mathrm{dpp}$ were treated with tamoxifen. Five days after tamoxifen treatment, the mice were killed by cervical dislocation. The testes were dissected and immediately fixed in $4 \%$ paraformaldehyde for up to $24 \mathrm{~h}$. The samples were then stored in $70 \%$ ethanol and embedded in paraffin. The paraffin-embedded samples were sectioned at a $5 \mu \mathrm{m}$ thickness and mounted on glass slides.

For immunohistochemistry, the tissue sections ( $5 \mu \mathrm{m}$ thick) were deparaffinized and rehydrated, followed by antigen retrieval in $10 \mathrm{mM}$ sodium citrate buffer for $15 \mathrm{~min}$. After washing the sections in PBS for 5 min, BSA was added to the sections to block nonspecific binding for $1 \mathrm{~h}$. Next, specific primary antibodies were added and incubated overnight at $4{ }^{\circ} \mathrm{C}$. The sections were then washed three times with PBS, and a secondary antibody was added to the sections for $1 \mathrm{~h}$ at room temperature. The sections were then washed three times in PBS prior to staining using a DAB substrate kit (Zhong Shan Technology, Beijing, China) and were counterstained with hematoxylin.

For immunofluorescence, $0.3 \%$ Triton $\mathrm{X}-100$ in PBS was used as the blocking buffer. Specific primary antibodies were added and incubated overnight at $4{ }^{\circ} \mathrm{C}$. The next day, the sections were washed three times with PBS and incubated with FITC- or TRITC-conjugated secondary antibodies (Jackson ImmunoResearch, West Grove, PA, USA) for $1 \mathrm{~h}$ at room temperature. The sections were then washed three times with PBS and counterstained with DAPI (Sigma) to visualize nuclei.

The following antibodies were used in this study: rabbit antiWt1 (1:200; Epitomics, Burlingame, CA, USA; 2797-1), mouse anti-Plzf (1:200; Abcam, Cambridge, UK; ab104854), rabbit anti-claudin11 (1:200; Abcam, ab53041), rabbit anti-laminin (1:400; Abcam, ab11575), and mouse anti-vimentin (1:500; Abcam, ab20346).

\section{Testis culture}

Testes from $W t 1^{-/ \text {flox }} ; C r e-E R^{T M}$ and $W t 1^{-/ \text {flox }}$ (control) mice at $5 \mathrm{dpp}$ were decapsulated and gently separated using two forceps into four to six pieces of 1-3 $\mathrm{mm}$ in diameter. The tissue fragments were then positioned on stands made of $1.5 \%$ agarose gel that were placed in a 24-well plate, as described previously (Sato et al. 2011) and pre-balanced to soak in culture medium overnight. The culture medium consisted of DMEM/F-12 (1:1; HyClone, Logan, UT, USA; SH30023.01B) with $10 \%$ fetal bovine serum (for embryonic stem cell use; Gibco). Next, 4-OH tamoxifen (Sigma, H7904) was added to the culture medium at a final concentration of $1 \mu \mathrm{M}$. The culture medium was replaced every 2 days, and the cells were cultured in $5 \%$ carbon dioxide in air and maintained at $33{ }^{\circ} \mathrm{C}$.

\section{Real-time PCR}

$W t 1^{-/ \text {flox }} ; C$ Cre-ER $R^{T M}$ and $W t 1^{-/ \text {flox }}$ mice were injected with tamoxifen at 5 dpp. Five days later, the testes were dissected, and total RNA was isolated using TRIzol (Invitrogen) according to the manufacturer's instructions. cDNA was synthesized using SuperScript III Reverse Transcriptase (Invitrogen) with random hexamers. Real-time PCR was performed using the SYBR Green Kit (Tiangen, Beijing, China) on a C1000 Thermal Cycler (Bio-Rad Laboratories). The primers used for real-time PCR amplification are listed in Table 1.

\section{Western blotting}

$W t 1^{-/ \text {flox }} ; C$ Cre-ER $R^{T M}$ and $W t 1^{-/ \text {flox }}$ mice were injected with tamoxifen at $5 \mathrm{dpp}$. Five days later, the testes were lysed in radio immunoprecipitation assay lysis buffer containing Complete Mini Protease Inhibitor Cocktail Tablets (Roche). The protein concentration in the supernatants was estimated using the Bradford assay (Bio-Rad Laboratories). The proteins were electrophoresed under reducing conditions in 10\% SDSPAGE gels and then transferred onto nitrocellulose membranes. The blots were incubated overnight at $4{ }^{\circ} \mathrm{C}$ with primary antibody, followed by $1 \mathrm{~h}$ of incubation at room temperature with HRP-labeled secondary antibody. Specific signals were detected using the ECL western blotting detection system.

The following antibodies were used in this study: mouse antiE-cadherin (BD, 610181), rabbit anti-N-cadherin (Santa Cruz, SC-7939), rabbit anti- $\beta$-catenin (Sigma, C2206), rabbit anti-occludin (Abcam, ab31721), and rabbit anti-PAR6 $\beta$ (Sigma, B8062).

Table 1 The primers used for real-time PCR amplification.

\begin{tabular}{|c|c|}
\hline Wt1 & $\begin{array}{l}\text { CCAGTGTAAAACTTGTCAGCGAAA } \\
\text { ATGAGTCCTGGTGTGGGTCTTC }\end{array}$ \\
\hline Plzf & CTGGGACTTTGTGCGATGTG \\
\hline Neurog3 & $\begin{array}{l}\text { AGTGCTCAGTTCCAATTCCAC } \\
\text { CGGCTTCTTCGCTTTTTGCTG }\end{array}$ \\
\hline Gfr $\alpha 1$ & $\begin{array}{l}\text { GTACAGGTCCGCCTACATCAC } \\
\text { GGCTGGAACTTTGTCGAAGAA }\end{array}$ \\
\hline Ret & $\begin{array}{l}\text { GCATGTCAGACCCGAACTGG } \\
\text { CGCTGAGGGTGAAACCATCC }\end{array}$ \\
\hline Nanos2 & $\begin{array}{l}\text { CTGCAAGCACAATGGGGAGT } \\
\text { CGTCGGTAGAGAGACTGCTG }\end{array}$ \\
\hline$G D N F$ & $\begin{array}{l}\text { CCAGTGACTCCAATATGCСТG } \\
\text { СТСТGCGAССТTTСССТСТG }\end{array}$ \\
\hline GAPDH & $\begin{array}{l}\text { TTGTCTCCTGCGACTTCAACA } \\
\text { ACCAGGAAATGAGCTTGACAAA }\end{array}$ \\
\hline
\end{tabular}



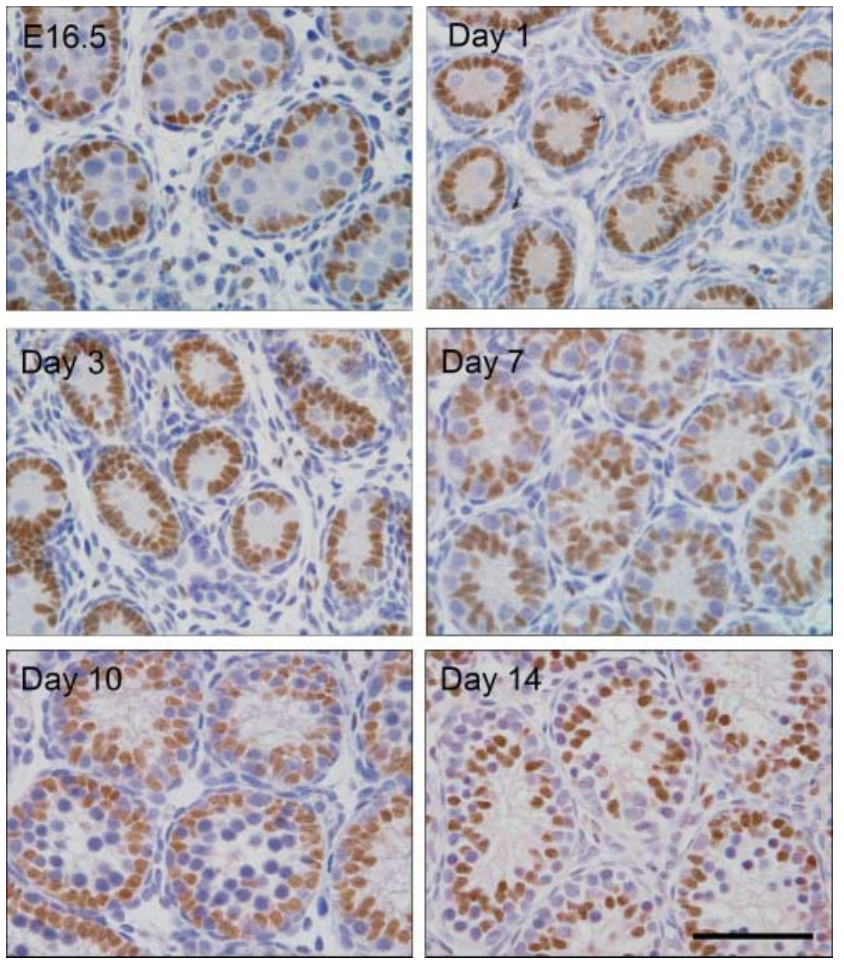

Figure $1 W t 1$ is specifically expressed in Sertoli cells in the seminiferous tubules of the developing testes. The testes of WT mice at E16.5 1, 3, 7, 10, and 14 dpp were immunostained with anti-Wt1 antibody. Scale bar $=50 \mu \mathrm{m}$.

\section{Statistical analysis}

The experiments were repeated at least three times. For the immunohistochemistry and immunofluorescence experiments, one representative image of the results of three independent experiments is presented. The data were evaluated for significant differences using Student's $t$-test. A $P$ value $<0.05$ was considered significant. Bar graphs were plotted using GraphPad Prism 6 (La Jolla, CA, USA).

\section{Results}

\section{Wt1 is specifically expressed in Sertoli cells in the seminiferous tubules of the developing testes}

To better understand the functions of $W t 1$ in developing testes, we first determined the spatiotemporal expression pattern of $W t 1$ protein in the WT mice from E16.5 to 14 dpp at six time points (E16.5, 1, 3, 7, 10, and $14 \mathrm{dpp}$ ). Testes from WT mice were embedded in paraffin and sectioned at a $5 \mu \mathrm{m}$ thickness. The tissue sections were then immunostained with anti-Wt1 antibody. As shown in Fig. 1, Wt1 is specifically expressed in Sertoli cells throughout the developmental stages.

\section{Wt1 is efficiently inactivated in $\mathrm{Wt}^{\text {/flox }}$; Cre-ER ${ }^{\mathrm{TM}}$ testes after tamoxifen treatment}

To inactivate $W t 1$ expression more efficiently, $W t 1^{-/ f l o x}$ mice were mated with $W t^{+/-}$; Cre-ER $R^{T M}$ mice to generate $W T 1^{- \text {flox }} ;$ Cre-ER $R^{T M}$ mice (KO group) and $W t 1^{- \text {fflox }}$ mice (control group). The littermate mice in both groups were indistinguishable, and the morphology and histology of the testes were normal compared with those of the WT testes (data not shown). To induce Cremediated recombinase activity, 5-dpp-old littermate mice from both groups were i.p. injected with tamoxifen at a dose of $9 \mathrm{mg} / 40 \mathrm{~g}$ (body weight). The use of the $W t 1^{- \text {fllox }}$; Cre-ER $R^{T M}$ mice allowed disruption of the $W t 1$ gene in an inducible manner, whereas the use of the $W t 1^{- \text {fflox }}$ mice did not. The testes were collected 5 days after tamoxifen injection. After Wt1 inactivation, the weight of both the body and the testis of the WT1-/flox; Cre- $E R^{T M}$ mice were significantly decreased compared with those of the control group (Fig. 2A and B), which was likely due to the negative effect of $W t 1$ inactivation on cardiovascular tissue and the kidney. However, the ratio of the testis weight:body weight was not affected (Fig. 2E).

Wt1-specific real-time PCR was used to examine the efficiency of tamoxifen-induced Cre recombination.

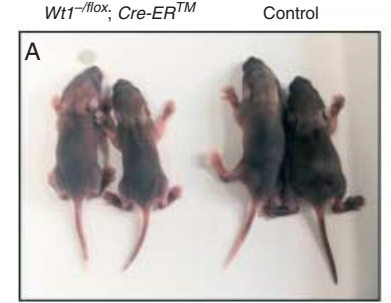

B
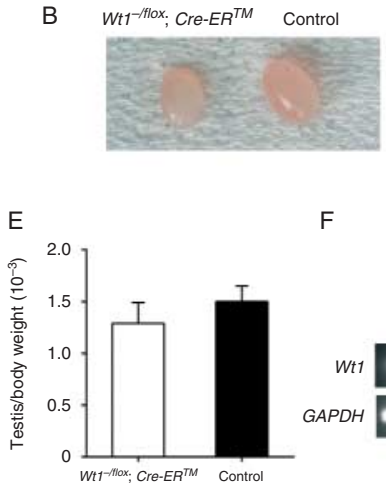

$\mathrm{F}$

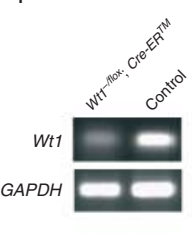

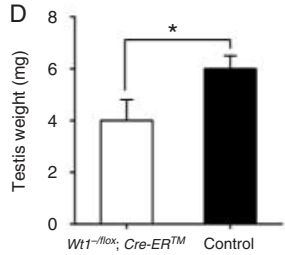

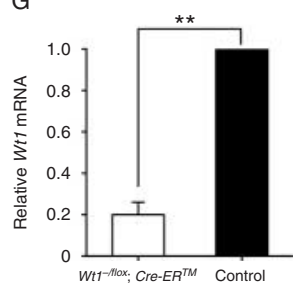

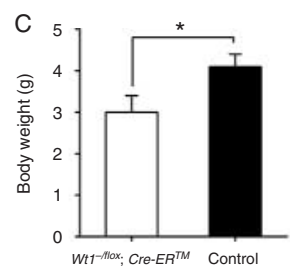

Figure $2 W t 1$ is mostly inactivated in $W t 1^{- \text {fflox }}$; Cre-ER $R^{T M}$ testes after tamoxifen treatment. (A and B) Comparison of the body and testis size of $W t 1^{- \text {flox }}$ (control) and $W t 1^{- \text {flox }} ; C r e-E R^{T M}$. (C and D) Quantitative analysis of the body weight and testes weight of $W t 1^{- \text {fflox }}$ (control) and $W t 1^{- \text {Iflox }}$ Cre-ER ${ }^{T M}$ mice. Both the body and the testis weights of the $W T 1^{- \text {fflox }}$; Cre-ER $R^{T M}$ mice were decreased compared with those of the control group ${ }^{*} P<0.05$. (E) Quantitative analysis of the ratio of testis weight:body weight in $W t 1^{- \text {fflox }}$ (control) and $W t 1^{- \text {fllox }}$; Cre-ER ${ }^{T M}$ mice. (F) Real-time PCR was performed using RNA isolated from $10 \mathrm{dpp} W t 1^{- \text {fflox }}$ (control) and $W t 1^{- \text {fllox }}$; Cre-ER $R^{T M}(\mathrm{KO})$ testes and specific primer pairs against $W t 1$ and GAPDH. Both the control and the $\mathrm{KO}$ mice were injected with tamoxifen at $5 \mathrm{dpp}$. For each sample, RNA from at least three animals was pooled. (G) Quantitative real-time PCR analysis of $W t 1 \mathrm{mRNA}$ expression in control and $\mathrm{KO}$ testes. The mRNA levels were normalized to GAPDH, and the S.D.s from duplicate reactions are shown $(* * P=0.006)$. 
The primers were designed to target the eighth and ninth exons, and thus, normal Wt1 mRNA could be detected, whereas disrupted Wt1 mRNA could not. The real-time PCR results showed that only $\sim 20 \%$ of normal Wt1 mRNA was still present in the $W t 1^{-/ f l o x}$; Cre-ER ${ }^{T M}$ testes compared with the control testes (Fig. 2G), indicating that $W t 1$ was mostly inactivated in the $W t 1^{- \text {fflox; }}$ Cre-ER ${ }^{T M}$ testes after tamoxifen treatment.

\section{Undifferentiated spermatogonia accumulate in Wt1-deficient testes}

Promyelocytic leukemia-associated protein $(P / z f)$ is a zinc finger transcription factor involved in germline stem cell self-renewal. Plzf expression is restricted to the gonocytes and undifferentiated spermatogonia (StarzGaiano \& Lehmann 2001, Santos \& Lehmann 2004). Prior to tamoxifen treatment, the number and distribution of Plzf-positive cells was nearly identical in the $W t 1^{- \text {fllox }}$; Cre-ER $R^{T M}$ and $W t 1^{- \text {flox }}$ testes at $5 \mathrm{dpp}$. After tamoxifen treatment, the number of Plzf-positive cells clearly showed a significant difference between the two groups (Fig. 3A). The number of Plzf-positive cells per tubule section was $\sim 16$ in the $W t 1^{-/ \text {flox }}$; Cre-ER $R^{T M}$ testes at $10 \mathrm{dpp}$, whereas only approximately eight were observed in the control group (Fig. 3B and C), indicating that undifferentiated spermatogonia abnormally accumulated after Wt1 inactivation. Also, the number of Plzf-positive cells/1000 Sertoli cells was counted (Fig. 3D). Three control testes and three $W t 1^{- \text {fflox; }}$; Cre- $E R^{T M}$ testes were used. Approximately 20 tubular cross sections were counted per animal. The average number of undifferentiated spermatogonia/1000 Sertoli cells was 208 in control testes, while in $W t 1^{- \text {fllox; }}$ Cre-ER ${ }^{T M}$ testes, the average number increased to 385.

Once $W t 1^{- \text {flox }}$; Cre-ER $R^{T M}$ mice were injected with tamoxifen, $W t 1$ was inactivated in all organs because of universal Cre expression. Wt1 has been reported to play an essential role in other organs, such as the kidney and heart. To eliminate the possible effect of other organs' ${ }^{\prime}$ t1 loss on testicular spermatogonia in vivo, the $W t 1^{-/ f l o x}$; Cre- $E R^{T M}$ testes were dissected at $5 \mathrm{dpp}$ and cultured on $1.5 \%$ agarose gel with $4-\mathrm{OH}$ tamoxifen to inactivate Wt1 expression. This method has a higher knockout efficiency and allows the direct observation of any alterations in the development of the seminiferous tubules.

The intermediate filaments in the Sertoli cells of postnatal mice consist of vimentin (Aumüller et al. 1992). Thus, vimentin immunostaining should reflect the Sertoli cell distribution in the seminiferous tubules. It was observed that in the $W t 1^{-/ \text {flox }}$; Cre- $E R^{T M}$ cultured testes, the number of Plzf-positive cells began to increase along the basal membrane from days 2-3. After 1 week in culture, the number of Plzf-positive cells exceeded the number in the control group (Fig. 4). The in vitro culture result confirmed our in vivo findings, with even more accumulation of undifferentiated spermatogonia.
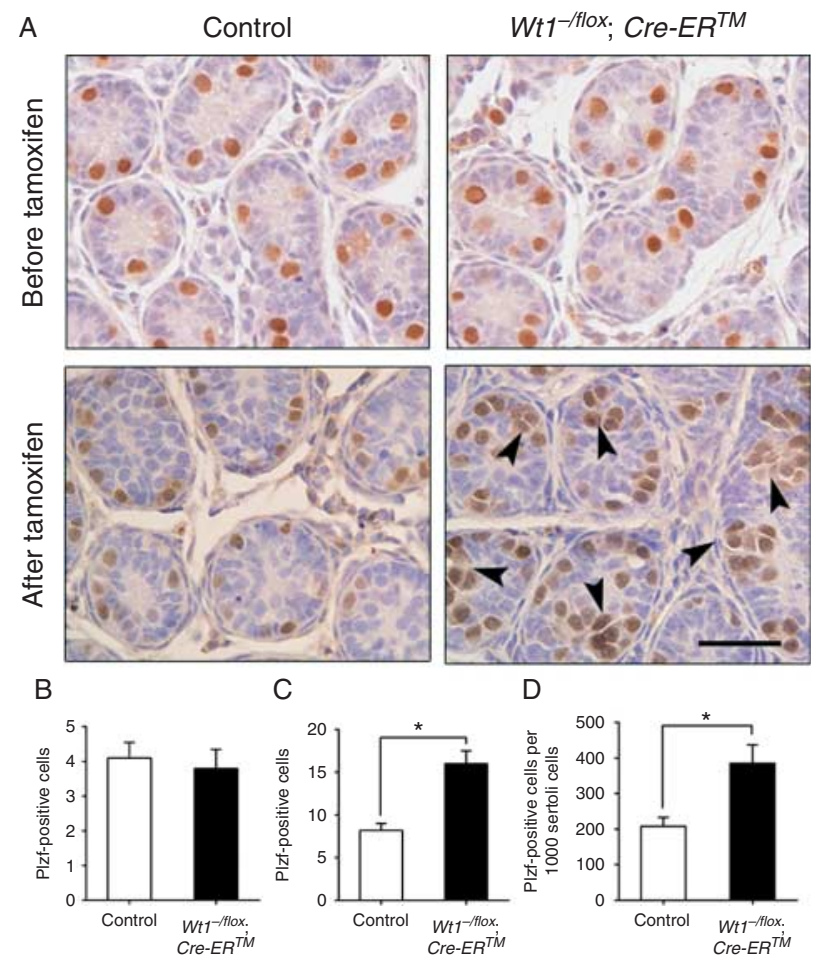

Figure 3 Undifferentiated spermatogonia accumulation in Wt1deficient testes. (A) $W t 1^{- \text {fllox }}$ (control) and $W t 1^{- \text {fflox }}$; Cre-ER ${ }^{T M}$ testes were immunostained for Plzf prior to tamoxifen treatment at $5 \mathrm{dpp}$ and 5 days after treatment (10 dpp). Plzf-positive cells accumulated and formed cell clusters (arrowhead). Scale bar $=50 \mu \mathrm{m}$. (B and C) The number of Plzf-positive cells per seminiferous tubule section was quantified. The data expressed as the mean \pm S.E.M. for at least three testes obtained from different mice $\left(^{*} P=0.065\right)$. (D) The number of Plzf-positive cells/1000 Sertoli cells was counted. The data are expressed as the mean \pm s.E.M. for three testes obtained from different mice.

\section{The expression of undifferentiated spermatogonia genes is upregulated after Wt1 inactivation}

Based on the finding that the number of undifferentiated spermatogonia increased after Wt1 deletion, we examined whether the expression of the undifferentiated spermatogonia-related genes Plzf, Neurog3 (Ngn3), Gfra1, Ret (C-Ret), and Nanos2 was also upregulated. Consistent with our anticipation, this gene expression increased remarkably compared with the expression in the control group (Fig. 5), indicating that the genes associated with undifferentiated spermatogonia were upregulated in the $W t 1^{- \text {flox }}$; Cre-ER ${ }^{T M}$ testes. Glial cell line-derived neurotrophic factor (GDNF) is a molecule secreted by Sertoli cells that promotes the proliferation of spermatogonial stem cells (Meng et al. 2000, Kubota et al. 2004, He et al. 2008). Although both the cell number and the related gene expression of undifferentiated spermatogonia increased in the $W t 1^{- \text {fllox; }}$; Cre-ER ${ }^{T M}$ testis, GDNF expression was maintained at the same level as in the control, indicating that the accumulation of undifferentiated spermatogonia may not have been caused by over-proliferation. 
A

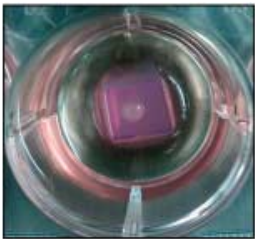

C
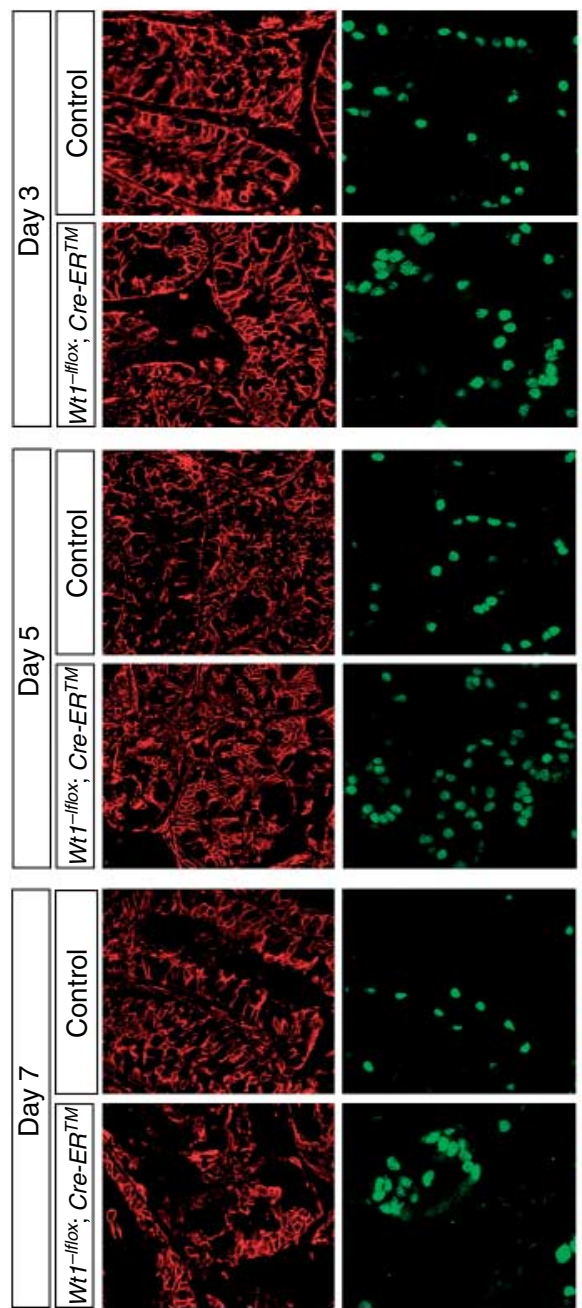

B

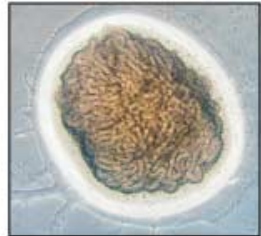

Plzf
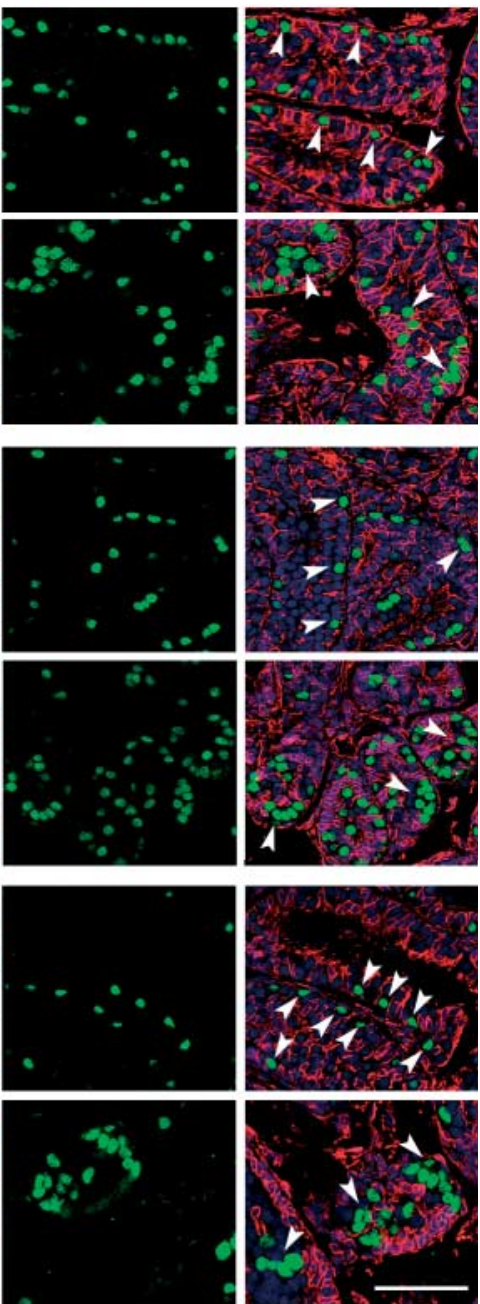

Figure 4 Plzf-positive cell accumulation in cultured testes after $W t 1$ inactivation. (A) In vitro culture of a testis segment on $1.5 \%$ agarose gel in DMEM/F-12 medium in a 24-well plate. (B) Using an inverted microscope, the cultured testicular segment could be observed. (C) Immunostaining of vimentin (red), Plzf (green), and Hoechst (blue) in the cultured testis at days 3,5 , and 7 . The arrowhead indicates undifferentiated spermatogonia. Scale bar $=50 \mu \mathrm{m}$.

\section{Germ cell differentiation is severely impaired after Wt1 inactivation}

At $10 \mathrm{dpp}$, the first wave of spermatogenesis had already entered the stage of meiosis in the normal mouse testis, as revealed by the Scp3 staining. By contrast, in the $W t 1^{- \text {fllox }}$; Cre-ER $R^{T M}$ testes, the germ cells lacked or had very low levels of $S c p 3$ expression (Fig. 6A).

Scp3, Dmc1, and Pgk2 are expressed in spermatocytes during meiosis (Robinson et al. 1989, Yuan et al. 2000,
Griswold et al. 2012). To examine the state of differentiation of the germ cells in the mouse testis after Wt1 inactivation, these marker genes were analyzed by realtime PCR (Fig. 6B). The statistical results showed that all the examined meiotic markers were markedly decreased in the $W t 1^{-/ f l o x}$; Cre-ER $R^{T M}$ mice compared with the controls. Together, with Scp3 staining, the results demonstrated that normal germ cell differentiation in the testis is severely impaired after Wt1 inactivation.

\section{The expression of claudin11 is severely impaired, whereas the integrity of the seminiferous tubules is not affected, in Wt1-deficient testes}

Laminin expression in the basal laminae of the seminiferous tubules has been reported during the development of the mouse testis (Gelly et al. 1989, Enders et al. 1995). Our study showed that the expression and distribution of laminin in the seminiferous tubules did not obviously differ between the control and the Wt1-deficient mice (Fig. 7A). This finding indicated that the integrity of the seminiferous tubules is not affected by $W t 1$ loss in the developing testis. The phenotype observed in our study is different from that of the embryonic stage, during which a loss of $W t 1$ results in a disruption of seminiferous tubule development and a subsequent progressive loss of Sertoli and germ cells (Gao et al. 2006, Chen et al. 2013). This discrepancy might be explained by different effects of $W t 1$ at various stages of testicular development.

Claudin11 is an obligatory protein in Sertoli cells for tight junction formation and blood-testis barrier integrity in the testis. Studies have shown that spermatogenesis does not proceed beyond meiosis in the absence of claudin11, resulting in male sterility (Gow et al. 1999, Mazaud-Guittot et al. 2010). Claudin11 was nearly absent in the Wt1-deficient testis (Fig. 7C and E),

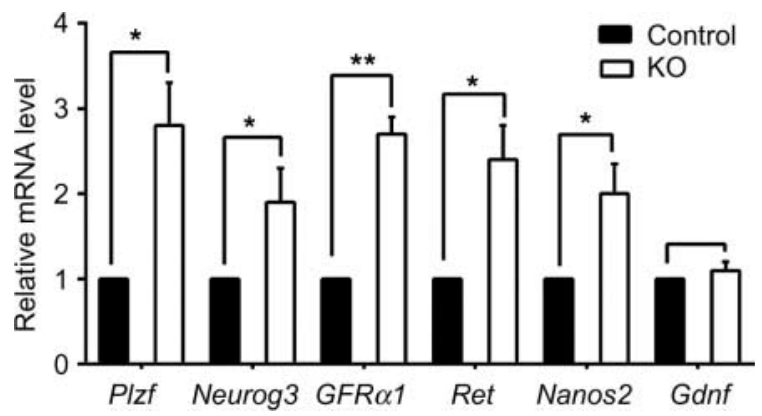

Figure 5 Expression of undifferentiated spermatogonia marker genes is increased after Wt1 inactivation. Real-time PCR was performed using RNA isolated from $10 \mathrm{dpp} W t 1^{- \text {fflox }}$ (control) and $W t 1^{- \text {fflox }}$; Cre-ER $R^{T M}$ (KO) testes and specific primer pairs against Plzf, Neurog3, Gfra1, Ret, Nanos2, Gdnf, and Gapdh. Mice from both the control and the KO groups were injected with tamoxifen at $5 \mathrm{dpp}$. Each of the combined samples was pooled from at least three animals. The mRNA levels were normalized to GAPDH, and the s.D.s from duplicate reactions are shown $(* P<0.05, * * P<0.01)$. 
A
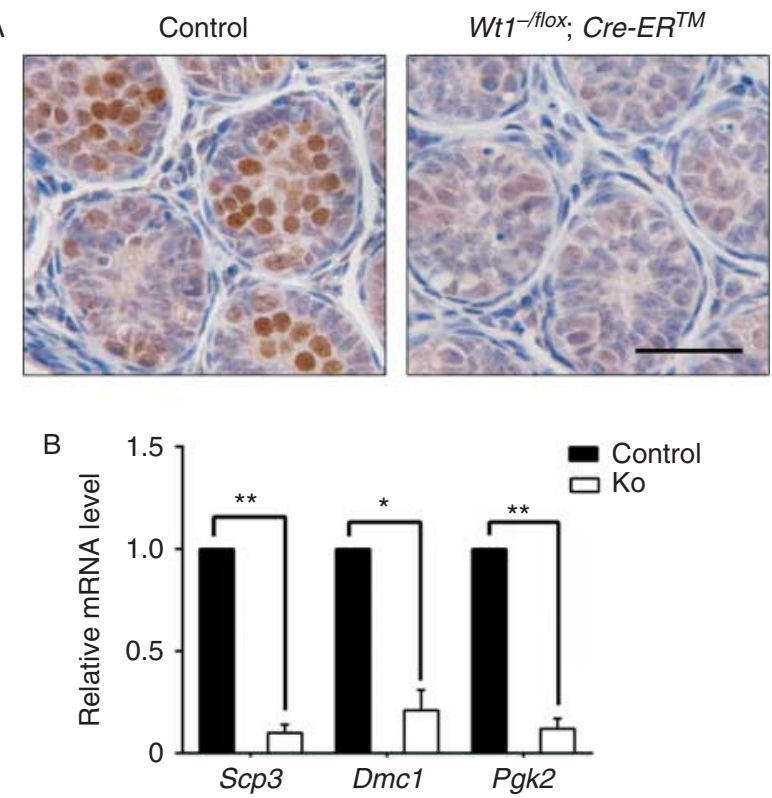

Figure 6 Meiotic progression disruption in $W t 1$-deficient testes. (A) Testes from $W t 1^{- \text {fflox }}$ (control) and $W t 1^{- \text {fllox }}$ C Cre-ER $E R^{T M}$ mice at $10 \mathrm{dpp}$ after tamoxifen treatment were immunostained using antibodies against Scp3. Scale bar $=50 \mu \mathrm{m}$. (B) RT-PCR was performed using RNAs isolated from $10 \mathrm{dpp} W t 1^{- \text {fllox }}$ (control) and $W t 1^{- \text {flox }}$; Cre-ER ${ }^{T M}$ (KO) testes and specific primer pairs against Scp3, Dmc1, Pgk2, and Gapdh. Mice from both the control and the KO groups were injected with tamoxifen at $5 \mathrm{dpp}$. For each sample, RNA from at least three animals was pooled. The mRNA levels were normalized to Gapdh, and the S.D.s from duplicate reactions are shown $\left({ }^{*} P<0.05,{ }^{* *} P<0.01\right)$.

whereas the protein's expression and localization were normal in the control testis (Fig. 7D and F). Because of blood-testis barrier formation at $\sim 2$ weeks after birth, a loss of claudin11 will result in the failure of SertoliSertoli tight junction formation in Wt1-deficient testes, eventually leading to meiosis failure.

\section{E-cadherin is downregulated in Wt1-deficient testes}

To investigate the underlying mechanism underlying the phenotype of $W t 1^{-/ f l o x}$; Cre- $E R^{T M}$ testes, several potential target proteins of $W t 1$ were measured by western blotting. All the molecules examined, except E-cadherin, showed no obvious change at the protein level within 5 days. Downregulation of E-cadherin after Wt1 loss was observed in $W_{t} 1^{- \text {fflox }}$; Cre- $E R^{T M}$ testes (Fig. $8 \mathrm{~A}$ ), whereas the expression of $\mathrm{N}$-cadherin, $\beta$-catenin, Par6b, and occludin remained the same in control testes.

\section{Discussion}

Sertoli cells are the only cell type that interacts with developing germ cells in the seminiferous tubules during testis development. Hence, the status of Sertoli cells is closely related to spermatogenesis. Here, we showed that Wt1 is specifically expressed in Sertoli cells in the seminiferous tubules of the developing testes. This observation is consistent with the results of previous reports on fetal and newborn testes (Pelletier et al. 1991, Mundlos et al. 1993). The spatiotemporal expression of Wt1 in Sertoli cells indicates the essential role of Wt1. However, the exact role of Wt1 during testis development has not been illuminated. In this study, we carefully observed the phenotype of Wt1-deficient mice and found that Wt1 deficiency causes undifferentiated spermatogonia accumulation and meiotic progression disruption in neonatal mice.

\section{The characterization of $\mathrm{Wt1}^{\text {/flox }}$; Cre-ER ${ }^{\mathrm{TM}}$ mice}

Wt1 has been reported to play an important role in gonad genesis and spermatogenesis (Gao et al. 2006, Klattig et al. 2007). Deletion of Wt1 in Sertoli cells at an early embryonic stage causes disruption of the testicular cord. Our recent study showed that inactivation of Wt1 in adult mice resulted in massive germ cell death and only Sertoli cells were present in most of the seminiferous tubules (Wang et al. 2013).

Immunohistochemical studies confirmed that the WT1 protein is strongly expressed in the Sertoli cells
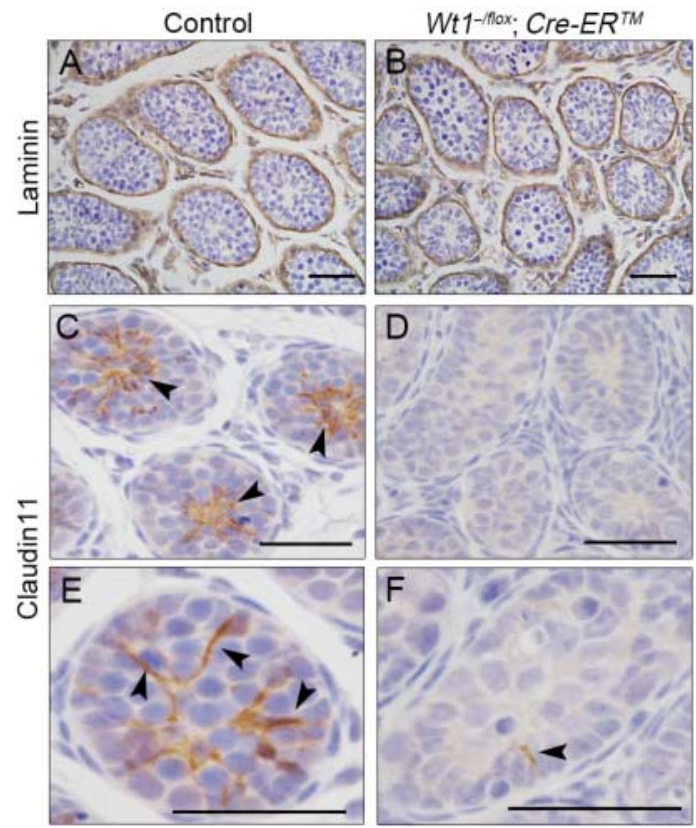

Figure 7 Expression of laminin and claudin11 in the testes from $W t 1^{-/ \text {flox }}$; Cre- $E R^{T M}$ and $W t 1^{-/ \text {flox }}$ (control) at $10 \mathrm{dpp}$ after tamoxifen treatment. (A and B) The testes of $W t 1^{- \text {flox }}$ and $W t 1^{- \text {flox }}$; Cre- $E R^{T M}$ mice at $10 \mathrm{dpp}$ after tamoxifen treatment were immunostained using antibodies against laminin. Laminin was expressed in the basal laminae of the seminiferous tubules, with no clear difference in the seminiferous tubules between $W t 1^{- \text {fflox }}$; Cre- $E R^{T M}$ and $W t 1^{- \text {fflox }}$ mice. $(C, D$, $\mathrm{E}$ and F) The testes from $W_{t} 1^{- \text {flox }}$ and $W t 1^{- \text {flox }}$; Cre- $E R^{T M}$ mice at $10 \mathrm{dpp}$ after tamoxifen treatment. Claudin 11 was mainly expressed in the Sertoli cells' junctions in the $W t 1^{- \text {fflox }}$ testis, whereas only very little caudin 11 (arrowhead) could be detected in the $\mathrm{Wt} 1^{- \text {fflox }}$; Cre-ER $R^{T M}$ testis. Scale bar $=50 \mu \mathrm{m}$. 

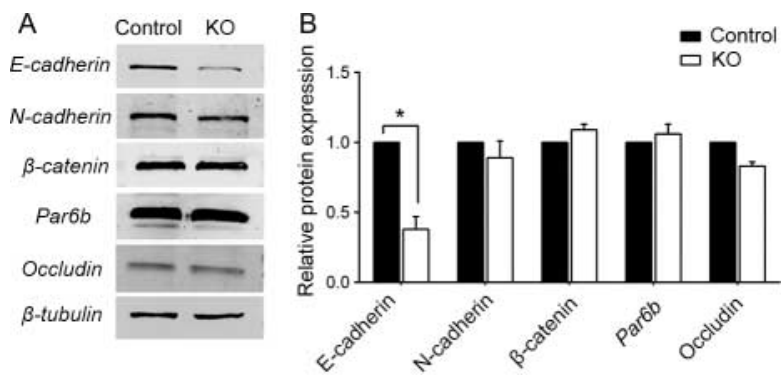

Figure $8 \mathrm{E}$-cadherin expression is decreased in Wt1-deficient testes. (A) Western blot analysis using specific antibiotics for E-cadherin, $\mathrm{N}$-cadherin, Par6b, and $\beta$-tubulin among the proteins isolated from $10 \mathrm{dpp}$ $W t 1^{- \text {flox }}$ (control) and $W t 1^{- \text {flox }}$; Cre-ER ${ }^{T M}(\mathrm{KO})$ testes. The control and $\mathrm{KO}$ mice were injected with tamoxifen at $5 \mathrm{dpp}$. (B) Quantification of the relative levels of E-cadherin, $\mathrm{N}$-cadherin, and Par6b (corrected to the total levels of their respective proteins) is shown $\left({ }^{*} P<0.05\right)$.

associated with the development of early spermatogonia, but not at a later stage of spermatogenesis (Suzuki \& Saga 2008). Therefore, we decided to inactivate $W t 1$ at 5 dpp. Tamoxifen-inducible Cre recombination was effective as soon as $12 \mathrm{~h}$, and the null allele in the $W t 1^{- \text {flox }}$; Cre-ER ${ }^{T M}$ mice resulted in a high inactivate efficiency. Real-time PCR analysis showed that the Wt1 mRNA level decreased by only $20 \%$ at $10 \mathrm{dpp}$. However, the $W t 1^{-/ \text {flox }}$; Cre-ER $R^{T M}$ mice revealed a low survival rate after tamoxifen treatment due to $W t 1$ loss-of-function in the kidney and heart. We injected tamoxifen at $5 \mathrm{dpp}$, and over $50 \%$ of $W t 1^{-/ \text {flox }}$; Cre-ER $R^{T M}$ mice (10 of 19 ) did not survive for more than 1 week. Thus, it was difficult to examine the phenotype after $12 \mathrm{dpp}$. To overcome this lethality due to the effects of Wt1 on other organs, we performed an in vitro testis culture on an agarose gel using a method developed by Sato et al. (2011).

A tissue-specific RNAi study revealed that mice depleted of WT1 in Sertoli cells suffered from increased germ cell apoptosis, loss of adherens junctions, and impaired fertility (Rao et al. 2006). In Rao's study, the mouse Pem (Rhox5) gene-driven promoter started expressing at $8 \mathrm{dpp}$, and Wt1 was inactivated thereafter. We speculate that the difference between our study and Rao's is mainly caused by different inactivation time. The first ten neonatal days are very crucial for Sertoli cell maturation and spermatogonia differentiation. Also, the phenotype in Rao's study was mainly observed at adult stage while our study focused on the developmental stage.

\section{The accumulation of undifferentiated spermatogonia is likely due to germ cell differentiation failure but not over-proliferation}

The undifferentiated spermatogonia increased in number and formed clusters after $W t 1$ inactivation. There might be two potential reasons for this phenomenon after $W t 1$ loss: differentiation arrest or over-proliferation of spermatogonia. Data obtained from our experiments showed that differentiation arrest might be the main reason. First, the total germ cell numbers within each tubule section showed no significant difference between the two groups. Secondly, there was clear meiotic arrest in the Wt1-deficient testes, which may have led to the increased number of undifferentiated spermatogonia. Moreover, the expression of GDNF (SSC self-renewal factor) in the $W t 1^{-/ f l o x} ;$ Cre- $E R^{T M}$ testis was comparable with the expression in the controls. These findings suggested that undifferentiated spermatogonia accumulation might be due to a failure in spermatogonia differentiation, rather than the cells' over-proliferation.

\section{Wt1 may regulate Sertoli cells' mesenchymal-epithelial balance via E-cadherin}

Many phenotypes in cancer and Wt1-deficient mice may be attributed to the proteins that regulate the mesenchymal-epithelial balance (Hohenstein \& Hastie 2006). In the first two neonatal weeks, Sertoli cells undergo a polarity establishment process for tight junction formation between cells, during which an apical-basal polarity is formed. Consequently, Sertoli cells adopt a more epithelial phenotype in the mesenchymalepithelial balance during this period.

Cadherins are $\mathrm{Ca}^{2+}$-dependent cell adhesion molecules that play an essential role in organogenesis (Raz 2004). E-cadherin is one of the cadherin family members that is involved in epithelial-mesenchymal transitions during cell development and tumor invasion (Donovan et al. 1986, Enders \& May 1994). Although E-cadherin is usually regarded as a specific marker for undifferentiated spermatogonia (Raz 2004, Kanatsu-Shinohara et al. 2008), E-cadherin expression in Sertoli cells is highest at 1 week after birth (Raz 2004). Previous studies have demonstrated that E-cadherin is a Wt1 target gene that regulates E-cadherin expression in NIH 3T3 cells and epicardial cells (Shinohara et al. 1999, Sharpe et al. 2003).

Wt1 might also regulate the mesenchymal-epithelial balance of Sertoli cells through E-cadherin in the neonatal testis given that upon Wt1 deletion, the mesenchymal-epithelial transition of Sertoli cells was impaired in the developing testis, resulting in meiotic arrest. Thus, we propose that $W t 1$ may affect Sertoli cells' mesenchymal-epithelial balance via upregulation of E-cadherin. However, the precise role of Wt1 in the developing testis needs to be further studied.

\section{Declaration of interest}

The authors declare that there is no conflict of interest that could be perceived as prejudicing the impartiality of the research reported.

\section{Funding}

This work was supported by the Major Research Plan '973' Project (2011CB944300, 2012CB944702), the National 
Technology Support Project (2012BAI31B08), and the National Nature Science Foundation of China (nos: 31171380, 31071018, and 31071271).

\section{References}

Aumüller G, Schulze C \& Viebahn C 1992 Intermediate filaments in Sertoli cells. Microscopy Research and Technique 20 50-72. (doi:10.1002/jemt. 1070200107)

Bacon K, Baggiolini M, Broxmeyer H, Horuk R, Lindley I, Mantovani A, Matsushima K, Murphy P, Nomiyama N, Oppenheim J et al. 2003 Chemokine/chemokine receptor nomenclature. Cytokine 21 48-49. (doi:10.1016/S1043-4666(02)00493-3)

Chamindrani Mendis-Handagama SML \& Siril Ariyaratne HB 2001 Differentiation of the adult Leydig cell population in the postnatal testis. Biology of Reproduction 65 660-671. (doi:10.1095/biolreprod65.3.660)

Chen S-R, Chen M, Wang X-N, Zhang J, Wen Q, Ji S-Y, Zheng Q-S, Gao F \& Liu Y-X 2013 The Wilms tumor gene, Wt1, maintains testicular cord integrity by regulating the expression of Col4a1 and Col4a2. BMC Biology 11 22. (doi:10.1186/1741-7007-11-22)

Donovan P, Stott D, Cairns L, Heasman J \& Wylie C 1986 Migratory and postmigratory mouse primordial germ cells behave differently in culture. Cell 44 831-838. (doi:10.1016/0092-8674(86)90005-X)

Enders G \& May J 1994 Developmentally regulated expression of a mouse germ cell nuclear antigen examined from embryonic day 11 to adult in male and female mice. Developmental Biology 163 331-340. (doi:10.1006/dbio.1994.1152)

Enders GC, Kahsai TZ, Lian G, Funabiki K, Killen PD \& Hudson BG 1995 Developmental changes in seminiferous tubule extracellular matrix components of the mouse testis: $\alpha 3$ (IV) collagen chain expressed at the initiation of spermatogenesis. Biology of Reproduction 53 1489-1499. (doi:10.1095/biolreprod53.6.1489)

Gao F, Maiti S, Alam N, Zhang Z, Deng JM, Behringer RR, Lecureuil C, Guillou F \& Huff V 2006 The Wilms tumor gene, Wt1, is required for Sox9 expression and maintenance of tubular architecture in the developing testis. PNAS 103 11987-11992. (doi:10.1073/pnas.0600994103)

Gelly JL, Richoux JP, Leheup BP \& Grignon G 1989 Immunolocalization of type IV collagen and laminin during rat gonadal morphogenesis and postnatal development of the testis and epididymis. Histochemistry 93 31-37. (doi:10.1007/BF00266844)

Gow A, Southwood CM, Li JS, Pariali M, Riordan GP, Brodie SE, Danias J, Bronstein JM, Kachar B \& Lazzarini RA 1999 CNS myelin and Sertoli cell tight junction strands are absent in Osp/claudin-11 null mice. Cell 99 649-659. (doi:10.1016/S0092-8674(00)81553-6)

Griswold MD, Hogarth CA, Bowles J \& Koopman P 2012 Initiating meiosis: the case for retinoic acid. Biology of Reproduction 35 31-37. (doi:10.1095/biolreprod.111.096610)

Harada N, Tamai Y, Ishikawa T, Sauer B, Takaku K, Oshima M \& Taketo MM 1999 Intestinal polyposis in mice with a dominant stable mutation of the $\beta$-catenin gene. EMBO Journal 18 5931-5942. (doi:10.1093/emboj/18. 21.5931)

Hayashi S \& McMahon AP 2002 Efficient recombination in diverse tissues by a tamoxifen-inducible form of Cre: a tool for temporally regulated gene activation/inactivation in the mouse. Developmental Biology 244 305-318. (doi:10.1006/dbio.2002.0597)

He Z, Jiang J, Kokkinaki M, Golestaneh N, Hofmann M-C \& Dym M 2008 Gdnf upregulates c-Fos transcription via the Ras/Erk1/2 pathway to promote mouse spermatogonial stem cell proliferation. Stem Cells $\mathbf{2 6}$ 266-278. (doi:10.1634/stemcells.2007-0436)

Hohenstein P \& Hastie ND 2006 The many facets of the Wilms' tumour gene, WT1. Human Molecular Genetics 15 R196-R201. (doi:10.1093/ hmg/ddl196)

Kanatsu-Shinohara M, Takehashi $M$, Takashima S, Lee J, Morimoto $H$, Chuma S, Raducanu A, Nakatsuji N, Fassler R \& Shinohara T 2008 Homing of mouse spermatogonial stem cells to germline niche depends on $\beta 1$-integrin. Cell Stem Cell 3 533-542. (doi:10.1016/j.stem.2008.08. 002)

Klattig J, Sierig R, Kruspe D, Makki MS \& Englert C 2007 WT1-mediated gene regulation in early urogenital ridge development. Sexual Development 1 238-254. (doi:10.1159/000104774)
Kreidberg JA, Sariola H, Loring JM, Maeda M, Pelletier J, Housman D \& Jaenisch R 1993 WT-1 is required for early kidney development. Cell 74 679-691. (doi:10.1016/0092-8674(93)90515-R)

Kubota H, Avarbock MR \& Brinster RL 2004 Growth factors essential for self-renewal and expansion of mouse spermatogonial stem cells. PNAS 101 16489-16494. (doi:10.1073/pnas.0407063101)

Luo X, Ikeda Y \& Parker KL 1994 A cell-specific nuclear receptor is essential for adrenal and gonadal development and sexual differentiation. Cell 77 481-490. (doi:10.1016/0092-8674(94)90211-9)

Mazaud-Guittot S, Meugnier E, Pesenti S, Wu X, Vidal H, Gow A \& Le Magueresse-Battistoni B 2010 Claudin 11 deficiency in mice results in loss of the Sertoli cell epithelial phenotype in the testis. Biology of Reproduction 82 202-213. (doi:10.1095/biolreprod.109.078907)

Meng X, Lindahl M, Hyvönen ME, Parvinen M, de Rooij DG, Hess MW, Raatikainen-Ahokas A, Sainio K, Rauvala H, Lakso M et al. 2000 Regulation of cell fate decision of undifferentiated spermatogonia by GDNF. Science 287 1489-1493. (doi:10.1126/science.287.5457.1489)

Mruk DD \& Cheng CY 2004 Sertoli-Sertoli and Sertoli-germ cell interactions and their significance in germ cell movement in the seminiferous epithelium during spermatogenesis. Endocrine Reviews 25 747-806. (doi:10.1210/er.2003-0022)

Mundlos S, Pelletier J, Darveau A, Bachmann M, Winterpacht A \& Zabel B 1993 Nuclear localization of the protein encoded by the Wilms' tumor gene WT1 in embryonic and adult tissues. Development 119 1329-1341.

Pelletier J, Schalling M, Buckler AJ, Rogers A, Haber DA \& Housman D 1991 Expression of the Wilms' tumor gene WT1 in the murine urogenital system. Genes and Development 5 1345-1356. (doi:10.1101/gad.5.8. 1345)

Rao MK, Pham J, Imam JS, MacLean JA, Murali D, Furuta Y, Sinha-Hikim AP \& Wilkinson MF 2006 Tissue-specific RNAi reveals that WT1 expression in nurse cells controls germ cell survival and spermatogenesis. Genes and Development 20 147-152. (doi:10.1101/gad1367806)

Raz E 2004 Guidance of primordial germ cell migration. Current Opinion in Cell Biology 16 169-173. (doi:10.1016/j.ceb.2004.01.004)

Robinson MO, McCarrey JR \& Simon MI 1989 Transcriptional regulatory regions of testis-specific PGK2 defined in transgenic mice. PNAS 86 8437-8441. (doi:10.1073/pnas.86.21.8437)

Santos A \& Lehmann R 2004 Germ cell specification and migration in Drosophila and beyond. Current Biology 14 R578-R589. (doi:10.1016/ j.cub.2004.07.018)

Sato T, Katagiri K, Gohbara A, Inoue K, Ogonuki N, Ogura A, Kubota Y \& Ogawa T 2011 In vitro production of functional sperm in cultured neonatal mouse testes. Nature 471 504-507. (doi:10.1038/nature09850)

Sharpe R, McKinnell C, Kivlin C \& Fisher J 2003 Proliferation and functional maturation of Sertoli cells, and their relevance to disorders of testis function in adulthood. Reproduction 125 769-784. (doi:10.1530/rep.0. 1250769)

Shinohara T, Avarbock MR \& Brinster RL 1999 \$1- and $\alpha 6$-integrin are surface markers on mouse spermatogonial stem cells. PNAS 96 5504-5509. (doi:10.1073/pnas.96.10.5504)

Starz-Gaiano M \& Lehmann R 2001 Moving towards the next generation. Mechanisms of Development 105 5-18. (doi:10.1016/S09254773(01)00392-6)

Suzuki A \& Saga Y 2008 Nanos2 suppresses meiosis and promotes male germ cell differentiation. Genes and Development 22 430-435. (doi:10.1101/gad.1612708)

Wang XN, Li ZS, Ren Y, Jiang T, Wang YQ, Chen M, Zhang J, Hao JX, Wang YB, Sha RN et al. 2013 The Wilms tumor gene, Wt1, is critical for mouse spermatogenesis via regulation of Sertoli cell polarity and is associated with non-obstructive azoospermia in humans. PLoS Genetics 9 e1003645. (doi:10.1371/journal.pgen.1003645)

Yuan L, Liu J-G, Zhao J, Brundell E, Daneholt B \& Höög C 2000 The murine SCP3 gene is required for synaptonemal complex assembly, chromosome synapsis, and male fertility. Molecular Cell 5 73-83. (doi:10.1016/ S1097-2765(00)80404-9)

Received 9 July 2013

First decision 30 July 2013

Revised manuscript received 10 October 2013

Accepted 15 October 2013 